\title{
A Statewide Quantitative Analysis of Computer Science: What Predicts CS in Georgia Public High School?
}

\author{
Miranda C. Parker \\ miranda.parker@gatech.edu \\ Georgia Institute of Technology \\ Atlanta, Georgia
}

\author{
Mark Guzdial \\ mjguz@umich.edu \\ University of Michigan \\ Ann Arbor, Michigan
}

\begin{abstract}
An estimated $35 \%$ of high school principals across the U.S. report teaching computer science (CS) at their schools, according to a 2018 code.org access report. Meanwhile, a growing number of organizations have missions of providing computer science to all students in primary and secondary schools. In order to reach all students with CS, we need to understand the choices students, teachers, and schools make regarding accessing CS education. In this poster, we present a regression model that predicts the percentage of students enrolled in a computer science course at a public high school in the U.S. state of Georgia. We choose a single state because the US school system is highly-distributed, so policy and standards contexts differ between states. Using publicly available data sets, we explore what could advance or diminish a school's choice to offer a CS course. Our results show that the explanatory variable that mostly highly correlates with and most strongly influences CS being offered in a school is whether CS has been offered before. The implication is that startup costs and inertia may be among the most critical factors, as opposed to wealth or size of the school district. Median income at the county level and enrollment numbers at a school do affect CS enrollment numbers, but only explain a small amount of the variance. We are currently undertaking qualitative work to understand the idiosyncratic factors that influence schools' decision to offer a CS course.
\end{abstract}

\section{CCS CONCEPTS}

- Social and professional topics $\rightarrow \mathrm{K}-12$ education.

\section{KEYWORDS}

computer science education, K-12 CS, regression analysis

ACM Reference Format:

Miranda C. Parker and Mark Guzdial. 2019. A Statewide Quantitative Analysis of Computer Science: What Predicts CS in Georgia Public High School?. In International Computing Education Research Conference (ICER '19), August 12-14, 2019, Toronto, ON, Canada. ACM, New York, NY, USA, 1 page. https://doi.org/10.1145/3291279.3341212

Permission to make digital or hard copies of all or part of this work for personal or classroom use is granted without fee provided that copies are not made or distributed for profit or commercial advantage and that copies bear this notice and the full citation on the first page. Copyrights for components of this work owned by others than ACM must be honored. Abstracting with credit is permitted. To copy otherwise, or republish, to post on servers or to redistribute to lists, requires prior specific permission and/or a fee. Request permissions from permissions@acm.org.

ICER '19, August 12-14, 2019, Toronto, ON, Canada

(c) 2019 Association for Computing Machinery.

ACM ISBN 978-1-4503-6185-9/19/08 _. \$15.00

https://doi.org/10.1145/3291279.3341212 